\title{
The Correlation between Students' Language Awareness and Learning Styles toward Their TOEFL Listening Skill
}

\author{
Aulia Putri \\ English Education Study Program \\ University of Riau Kepulauan \\ auliaputri1983@yahoo.com
}

\begin{abstract}
The aim of this research was to see the correlation between students' language awareness and learning styles toward their TOEFL listening skill of English Education Study Program, University of Riau Kepulauan (UNRIKA). This research used quantitative method with correlational research design. The selection of research subject used total sampling of 60 students. Data were collected by using 2 questionnaires for students' language awareness and learning styles variables, as well as the listening test to measure their TOEFL listening skill. This research was analyzed by using Pearson product moment formula and multiple regression to get multiple correlation coefficient (r). From the results of analysis, it was found that the coefficient of multiple correlation $(r)=0.1763$, where $r$ ranged from 0.00 - 0.1999. This meant that there was a very low correlation between language awareness $\left(X_{1}\right)$ and learning styles $\left(X_{2}\right)$ to the dependent variable of students' TOEFL listening skill. While the coefficient of determination $\left(r^{2}\right)=$ 0.028 which meant that $2.8 \%$ variation of the independent variables of language awareness $\left(X_{1}\right)$ and learning styles $\left(X_{2}\right)$ can explain the variation of dependent variable of students' TOEFL listening skill.
\end{abstract}

Keywords: language awareness, learning styles, TOEFL listening skill

\section{INTRODUCTION}

In lectures at the University of Riau Kepulauan, students 'English proficiency contributed to their graduation. Each student is expected to have sufficient English skills to face the real world after completing their education. The measurement of students' English proficiency in UNRIKA is by looking at the TOEFL score. Specifically, each student is required to have a TOEFL score of at least 450 to be considered worth passing. In this TOEFL, there are 3 language skills tested: listening, grammar, and reading skill. This is in accordance with the type of TOEFL that is used for campus which is Paper-based TOEFL.

The achievement of a person in mastering language skills is varied. Many factors that support a person to be able to have good language skills, among them are language 
awareness and learning styles. Everybody has different language awareness and learning styles. There are people with a high level of awareness and some who are not aware of language. Moreover, someone's learning style is also not the same; one might have visual, audio, or kinaesthetic learning style. This depends on each other's habits.

Based on the above explanation, the researcher interested to see the correlation between students' language awareness and learning styles toward their listening skills. In this case the researcher would like to see the listening skills of students in TOEFL, where TOEFL become one of the requirements to get their first degree, especially in English education study program, so the researcher intends to carry out the research entitled "The Correlation between Students' Language Awareness and Learning Styles toward their TOEFL Listening Skill”.

\section{Language Awareness}

Language awareness according to Komorowska in Łyda and Szczes'niak (2014:06) is a person's sensitivity and awareness of the nature of language and its role in human life in Svalberg (2007). Further Komorowska in Łyda and Szczes'niak (2014:07), in a particular approach, mentions language awareness is not only related to consciousness, but also to the ability to pronounce and communicate one's understanding to others. Carter (2003) in Lin (2011) said that language awareness refers to the development in learners of an enhanced consciousness of and sensitivity to the forms and functions of language. The concept began to gain currency in the 1980 s as a reaction to the then prevailing prescriptive approach which focuses on forms and atomistic analysis of a language. Two distinctive features of language awareness is that: First, it studies language in a larger social, cultural and ideological framework rather than typifying a language by meticulous study; Second, language awareness is an attribute gained through learners' motivated attention to a language in use (Tomlinson, 2003) in Lin (2011). It's a developmental process achieved by learners own experience and discovery of how language works.

\section{Learning Styles}

Learning styles according to Pritchard (2009:51) are defined variously such as: the particular way in which a person learns; learning mode - the preferred or best way for a person to think, the process of information and learning demonstration; the way someone likes to acquire knowledge and skills; habits, strategies, or ordinary mental behaviors of learning, especially educational learning, that a person displays. 
Furthermore, Pritchard (2009:44-45) also explains that there are three kinds of specific learning styles, namely:

\section{Visual learning style}

In the visual learning style, learners prefer to learn by looking. Students with this learning style prefer information displayed in the form of charts, graphs, maps, or posters. Another feature of visual learners is that they often use hand gestures to describe situations or objects.

\section{Auditory learning style}

Auditory learners enjoy learning while listening. They have a good auditory memory of discussion, listening to lectures, interviewing, listening to stories, and from tape. Their tendency is that they like something traceable, repetitive and conclusive. When remembering something, they like to tilt their head and often move their eyes.

\section{Kinaesthetic learning style}

Students with kinesthetic learning styles love how to learn from doing something or by practicing it. They love physical activities, travel, and other practical lessons. In addition, kinesthetic learners are also hard to keep quiet and need break time in classroom activities.

\section{The Definition of Listening}

Nunan in Al-Alwan, et al (2013) explains that listening is an active process involving the deciphering and composing meaning of verbal and non-verbal messages. Moreover, Scarcella and Oxford in Bidadabi and Yamat (2011) say that listening is an important ability where this ability develops faster than speech. Often this listening ability affects the development of reading and writing skills in learning a new language.

From the above understanding, it can be concluded that listening is an ability which is a process of understanding the messages received which can be delivered in spoken or not.

\section{Types of Listening}

There are several types of listening that have been identified:

\section{Active Listening}

Active learners make sound judgments about what is heard. Probably, they write down important ideas in complete sentences. Furthermore, they may listen for ideas more than details.

\section{Partial Listening}

They are those who are thinking of their next reply rather than listening to what is 
happening.

\section{Intermittent Listening}

These learners are deaf and they close their ears to unpleasantness. They are those who instinctively nod and shake their heads in conformity when they are not listening at all.

\section{Appreciate Listening}

A good listener practically absorbs all the speaker's meaning by being responsive to tone of voice, facial expression, and bodily action as well as to the words themselves. (Sharifian, 2009) in Ashemota (2015).

Moreover, Tyagi (2011) explains that listening includes of some key components, they are: discerning between sounds, identifying words and knowing their meaning, recognizing grammatical groupings of words, identifying terms and sets of expressions that act to create meaning, linking linguistic cues to non-linguistic and paralinguistic cues, using background knowledge to expect and to verify meaning and recalling significant words and ideas.

\section{METHODOLOGY}

This research was a correlational quantitative research using three variables. There were two variables $\mathrm{X}$-language awareness and learning style. Variable $\mathrm{Y}$ is students' TOEFL listening skill. The population of this research was all students of seventh semester of English Education Study Program of of University of Riau Kepulauan consisted of of 50 students. As a result, the sampling techinique was taken as the sample for the research.

Data were obtained from TOEFL listening test, language awareness questionnaire, and learning style questionnaire. While for analyzing the data, the researcher used Pearson Product Moment Correlation Coefficient formula and multiple regression formula to get multiple correlation coefficient. Before the data was analyzed by using multiple regression analysis, then first research assumption test was done by normality test.

\section{RESULTS}

The results of the research were obtained by using the Language Awareness Questionnaire, Learning Style Questionnaire, and TOEFL listening test with the aim of the research to prove whether or not there is correlation between students' language awareness and learning stage toward their TOEFL listening skill. 


\section{Language Awareness}

Table 1. Data description of language awareness

\begin{tabular}{lccccc}
\hline & N & Minimum & Maximum & Mean & $\begin{array}{c}\text { Std. } \\
\text { Deviation }\end{array}$ \\
\hline $\begin{array}{l}\text { Language } \\
\text { Awareness }\end{array}$ & 50 & 48 & 108 & 79.70 & 15.53 \\
\hline
\end{tabular}

From the calculation of a questionnaire containing 25 items of statements, it is obtained the range of minimum score is 48 and maximum score is 108 . The average score (mean) is 79.70. From the data, standard deviation was obtained 15.53. Then, from the given questionnaire, it also can be seen the level of language awareness that is owned by the seventh semester of English Education Study Program of Universitas of Riau Kepulauan. The level of language awareness that the students had:

Table 2. Data description of students' level of language awareness

\begin{tabular}{clc}
\hline Scale & \multicolumn{1}{c}{$\begin{array}{c}\text { Awareness } \\
\text { Response }\end{array}$} & Total \\
\hline 1 & not at all aware & 0 \\
\hline 2 & slightly aware & 7 \\
\hline 3 & moderately aware & 26 \\
\hline 4 & very aware & 17 \\
\hline 5 & extremely aware & 0 \\
\hline
\end{tabular}

From the calculation of questionnaires containing 25 items of statements, it is obtained the mean score for the level of language awareness, where the level of language awareness of "slightly aware" with a scale of 2 as many as 7 students; "moderately aware" with a scale of 3 as many as 26 students; and "very aware" with a scale of 4 as many as 17 students.

\section{Learning Styles}

Table 3. Data description of learning styles

Std.

\begin{tabular}{cccccc} 
& N & Minimum & Maximum & Mean & Deviation \\
\hline Learning Styles & 50 & 38 & 69 & 56.70 & 6.11 \\
\hline
\end{tabular}


From the calculation of a questionnaire containing 15 statements, it is obtained the range for minimum score is 38 and maximum score is 69 . The average score (mean) is 56.70 . From the data, it is obtained standard deviation of 6.11 .

Then, from the given questionnaire, it can also be seen the tendency of learning styles owned by seventh semester students of English Education Study Program of University of Riau Kepulauan, they are:

Table 4. Data description of students' learning styles

\begin{tabular}{cccc} 
Learning Styles & Visual & Auditory & Kinaesthetic \\
\hline Mean & 3.8 & 3.7 & 3.8 \\
\hline
\end{tabular}

From the calculation of a questionnaire containing 15 items of statements, it is obtained the mean score for the visual learning style of 3.8; auditory learning style of 3.7; and kinaesthetic learning style of 3.8.

\section{Students' TOEFL Listening Skill}

Table 5. Data description of students' TOEFL listening skill

\begin{tabular}{lccccc}
\hline & N & Minimum & Maximum & Mean & $\begin{array}{c}\text { Std. } \\
\text { Deviation }\end{array}$ \\
\hline $\begin{array}{l}\text { TOEFL } \\
\text { Listening Skill }\end{array}$ & 50 & 320 & 570 & 434.20 & 59.33 \\
\hline
\end{tabular}

From the calculation of TOEFL listening test containing 50 questions, it is obtained the range for minimum score of 320 and maximum score of 570. The average score (mean) is 434.20. From the data, it is obtained standard deviation of 59.88. Before the data is analyzed by using multiple regression analysis, and then first research assumptions test is done which is Normality Test. The normality test is performed to determine whether the data from the three research variables obtained come from the data that is normally distributed. The data tested were the distribution of data on the Language Awareness Questionnaire, the Learning Style Questionnaire, and students' TOEFL listening test. Normality test of the data used ChiSquare Test.

Table 6. Normality test of language awareness

\begin{tabular}{lc}
\hline & Language Awareness \\
\hline $\mathbf{N}$ & 50 \\
\hline Mean & 79.7 \\
\hline Std.Deviation & 15.53 \\
\hline
\end{tabular}




\begin{tabular}{ll}
\hline Chi-Square & 8.8 \\
\hline
\end{tabular}

By comparing the value of $\mathrm{X}_{1}$ count with $\mathrm{X}_{1}$ table value for alpha $=0.05$ and degrees of freedom $(\mathrm{df})=\mathrm{k}-1=7-1=6$, then from Chi-Square table, it is obtained $\mathrm{X}_{2}$ table $=12.6$ with the following test criteria:

If $\mathrm{X}_{1}$ count $>\mathrm{X}_{1}$ table, it means data distribution is abnormal

If $X_{1}$ count $<X_{1}$ table, it means data distribution is normal

It turns out that $\mathrm{X}_{1}$ count $<\mathrm{X}_{1}$ table, or $8.8<12.6$, then $\mathrm{H} 0$ is accepted. Thus, the questionnaire data of students' language awareness in $7^{\text {th }}$ semester UNRIKA is normal distribution. Thus, further test analysis can be performed.

Table 7. Normality test of learning styles

\begin{tabular}{lc}
\hline & Learning Styles \\
\hline $\mathbf{N}$ & 50 \\
\hline Mean & 56.7 \\
\hline Std.Deviation & 6.11 \\
\hline Chi-Square & 2.9 \\
\hline
\end{tabular}

By comparing the value of $\mathrm{X}_{2}$ count with $\mathrm{X}_{2}$ table value for alpha $=0.05$ and degrees of freedom $(\mathrm{df})=\mathrm{k}-1=7-1=6$, then from Chi-Square table, it is obtained $\mathrm{X}_{2}$ table $=12.6$ with the following test criteria:

$$
\begin{aligned}
& \text { If } X_{2} \text { count }>X_{2} \text { table, it means data distribution is abnormal } \\
& \text { If } X_{2} \text { count }<X_{2} \text { table, it means data distribution is normal }
\end{aligned}
$$

It turns out that $\mathrm{X}_{2}$ count $<\mathrm{X}_{2}$ table, or $2.9<12.6$, then $\mathrm{H} 0$ is accepted. Thus, the questionnaire data of students' learning styles in $7^{\text {th }}$ semester UNRIKA is normal distribution. Thus, further test analysis can be performed.

Table 8. Normality Test of Students' TOEFL Listening Skill

\begin{tabular}{cc}
\hline & TOEFL Listening Skill \\
\hline $\mathbf{N}$ & 50 \\
\hline Mean & 434.2 \\
\hline Std.Deviation & 59.33 \\
\hline Chi-Square & 6.16 \\
\hline
\end{tabular}


By comparing the value of $\mathrm{Y}_{\text {count }}$ with $\mathrm{Y}_{\text {table }}$ value for alpha $=0.05$ and degrees of freedom $(\mathrm{df})=\mathrm{k}-1=7-1=6$, then from Chi-Square table, it is obtained $\mathrm{Y}_{\text {table }}=12.6$ with the following test criteria:

$$
\begin{aligned}
& \text { If } \mathrm{Y}_{\text {count }}>\mathrm{Y}_{\text {table }} \text {, it means data distribution is abnormal } \\
& \text { If } \mathrm{Y}_{\text {count }}<\mathrm{Y}_{\text {table }} \text {, it means data distribution is normal }
\end{aligned}
$$

It turns out that $\mathrm{Y}_{\text {count }}<\mathrm{Y}_{\text {table, }}$ or $6.16<12.6$, then $\mathrm{H} 0$ is accepted. Thus, the students' TOEFL Listening Skill score in $7^{\text {th }}$ semester UNRIKA is normal distribution. Thus, further test analysis can be performed.

\section{Hypotheses Test}

To test the first and second hypothesis of the research, which are (1) to see the correlation between students' language awareness and their TOEFL listening skill of English Education Study Program of University of Riau Kepulauan and (2) to see the correlation between students' learning style and their TOEFL listening skill of English Education Study Program of University of Riau Kepulauan; the researcher used the formula of Pearson Product Moment Coefficient of Correlation.

\section{Correlation between Students' Language Awareness and Their TOEFL Listening Skill}

Table 9. Hypothesis test 1
\begin{tabular}{lc}
\hline $\mathbf{R}$ & -0.096 \\
\hline $\mathbf{t}$-count & -0.0668 \\
\hline
\end{tabular}

\section{Test rules:}

If $t_{\text {test }} \geq t_{\text {table }}$, then $\mathrm{H} 0$ is rejected, it means there is a correlation and $\mathrm{t}_{\text {test }} \leq \mathrm{t}_{\text {table }}$, then $\mathrm{H} 0$ is accepted, it means there is no correlation

Based on the above calculation, $\alpha=0.05$ and $n=50$, test of two parties:

$$
\mathrm{df}=\mathrm{n}-2=50-2=48 \text { so } \mathrm{t}_{\text {table }}=2.01063
$$

It turns out that $\mathrm{t}_{\text {test }}$ is smaller than $\mathrm{t}_{\text {table, }}$ or $-0.668<2.01063$, then $\mathrm{H} 0$ is accepted, it means there is no significant correlation between students' language awareness and students' TOEFL listening skill.

\section{Correlation between Students' Learning Styles and Their TOEFL Listening Skill}

Table 10. Hypothesis test 2

\begin{tabular}{cc}
\hline $\mathbf{R}$ & -0.151 \\
\hline $\mathbf{t}_{\text {test }}$ & -1.07 \\
\hline
\end{tabular}

\section{Test rules:}


If $t_{\text {test }} \geq t_{\text {table, }}$, then $\mathrm{H} 0$ is rejected, it means there is a correlation and $t_{\text {test }} \leq t_{\text {table, }}$, then $\mathrm{HO}$ is accepted, it means there is no correlation

Based on the above calculation, $\alpha=0.05$ and $n=50$, test of two parties:

$$
\mathrm{df}=\mathrm{n}-2=50-2=48 \text { so } \mathrm{t}_{\text {table }}=2.01063
$$

It turns out that $\mathrm{t}_{\text {test }}$ is smaller than $\mathrm{t}_{\text {table, }}$ or $-1.071<2.01063$, then $\mathrm{H} 0$ is accepted, it means there is no significant correlation between students' learning styles and students' TOEFL listening skill.

\section{The Correlation between Students' Language Awareness and Learning Styles toward Their TOEFL Listening Skill}

Table 11. Hypothesis test 3

\begin{tabular}{cc}
\hline$r^{2}$ & 0.028 \\
\hline$r$ & 0.1673 \\
\hline
\end{tabular}

From the analysis results above, it can be seen that the coefficient of multiple correlation $(r)=0.1763$, where $r$ ranges from $0.00-0.1999$. This means that there is a very low correlation between language awareness $\left(\mathrm{X}_{1}\right)$ and learning styles $\left(\mathrm{X}_{2}\right)$ toward the dependent variable of students' TOEFL listening skill. While the coefficient of determination $\left(r^{2}\right)=0.028$ which means that $2.8 \%$ variation of the independent variable of language awareness $\left(\mathrm{X}_{1}\right)$ and learning styles $\left(\mathrm{X}_{2}\right)$ can explain the variation of dependent variable; students' TOEFL listening skill.

\section{DISCUSSION}

There is no correlation between language awareness and TOEFL listening skill of the seventh semester students of English Education Program of University of Riau Kepulaua. There is no correlation between learning styles and TOEFL listening skill of $7^{\text {th }}$ semester students of English Education Program of University of Riau Kepulauan. There is a very low correlation between language awareness $\left(\mathrm{X}_{1}\right)$ and learning styles $\left(\mathrm{X}_{2}\right)$ to the dependent variable; students' TOEFL listening skills of $7^{\text {th }}$ semester students of English Education Program of University of Riau Kepulauan.

\section{REFERENCES}

Al-Alwan, Ahmed et.al. (2013). EFL learners' listening comprehension and awareness of metacognitive strategies: How are they related? Retrieved from: http://dx.doi.org/10.5539/ies.v6n9p31. 
Asemota, Henry Erhamwenmwonyi. (2015). Nature, importance and practice of listening skill. British Journal of Education Vol.3, No.7, pp.27-33, July 2015 Retrieved from: http://www.eajournals.org/wp-content/uploads/Nature-Importance-and-Practice-ofListening-Skill.pdf.

Bidadabi, Farinaz Shirani and Hamidah Yamat (2011). The relationship between listening strategies used by Iranian EFL freshman university students and their listening proficiency levels. Retrieved from: http://www.ccsenet.org/elt.

Lin, Yi. (2011). A language awareness approach to English language teaching in joint programs in China. Retrieved from: http://paaljapan.org/conference2011/ProcNewest2011/pdf/oral/2A-1.pdf.

Lyda, Andrzej and Konrad Szcesniak (2014). Awareness in action: The role of onsciousness in language acquisition. Switzerland: Springer International Publishing.

Pritchard, Alan (2009). Ways of learning: Learning theories and learning styles in classroom. New York: Routledge.

Tyagi, Babita. (2011). Listening: An important skill and its various aspects the criterion. An International Journal in English. Retrieved from: http://www.thecriterion.com/V4/n1/Babita.pdf 